\title{
Hematological Reference Values for Healthy Adults in Togo
}

\author{
Irenee Messanh Kueviakoe, ${ }^{1}$ Akuete Yvon Segbena, ${ }^{1}$ Helene Jouault, ${ }^{2}$ Ahoefa Vovor, ${ }^{3}$ \\ and Michele Imbert ${ }^{2}$
}

${ }^{1}$ Hematology Laboratory, Campus Teaching Hospital, University of Lome, 03 bp 30284 Lome-Togo, Togo

${ }^{2}$ Hematology Laboratory, Henri Mondor Hospital, 94000 Creteil, France

${ }^{3}$ Hematology Laboratory, Tokoin Teaching Hospital, Lome, 01 bp57 Lome-Togo, Togo

Correspondence should be addressed to Irenee Messanh Kueviakoe, kueviam@hotmail.com

Received 24 August 2010; Accepted 8 September 2010

Academic Editors: A. G. Tsai, J. L. Vives-Corrons and B. Wachowicz

Copyright (C) 2011 Irenee Messanh Kueviakoe et al. This is an open access article distributed under the Creative Commons Attribution License, which permits unrestricted use, distribution, and reproduction in any medium, provided the original work is properly cited.

\begin{abstract}
The hematological reference values are very important for diagnostic orientation and treatment decision. The aim of this study was to establish hematological reference values for healthy adults in Togo. A total of 2571 voluntary blood donors participated to this study. Only 1349 subjects negative for HIV, HBV, HCV, malaria, and without hemoglobin abnormalities in electrophoresis and hypochromia on blood smear, were definitively retained for the study. Median hemoglobin level was higher in males than females $(15.1 \mathrm{~g} / \mathrm{dL}$ versus $13.0 \mathrm{~g} / \mathrm{dL}, p=0.000)$. Median total WBC $\left(4.2 \times 10^{9} / \mathrm{L}\right)$ and absolute neutrophil counts $\left(1.6 \times 10^{9} / \mathrm{L}\right)$ were similar by gender. The median lymphocyte counts in males and females were, respectively, $2.1 \times 10^{9} / \mathrm{L}$ and $2.2 \times 10^{9} / \mathrm{L}(p=0.11)$. The median platelet count was lower in males than females $\left(236 \times 10^{9} / \mathrm{L}\right.$ versus $\left.247 \times 10^{9} / \mathrm{L}, p=0.004\right)$. Our median values for RBC parameters differ from those of African countries probably because of our inclusion criteria which eliminate most cases with iron deficiency and/or thalassemia.
\end{abstract}

\section{Introduction}

In daily practice in Togo, it is important to have hematological reference values for diagnosis orientation and treatment decision. The hematological reference values were determined many years ago for the Caucasian's populations [1-3]. Recently, several authors tried to establish reference values in hematology for African countries. However there are some discrepancies from one study to another which may be related to different factors such as age, sex, geographic origin, altitude, and ethnic origin [4-10]. Moreover, many constitutional hemoglobin abnormalities (thalassemia, sickle cell disease and hemoglobin $\mathrm{C}$ ) or pathologic conditions (malaria, HIV, HBV and HCV viral infections), influence the hematological values.

Togo is a Western African country, with an altitude below 1000 meters. Until now, hematological reference values have not been established. The values usually used are those of Caucasian populations. In Togo, it is especially difficult to establish hematological reference values for RBC parameters because of the (i) high frequency of alpha-thalassemia
(49.2\%), (ii) beta-globin gene abnormalities (37.5\%), [11], and, (iii) iron deficiency anemia in the overall population.

According to this context and for a better interpretation of hematologic results, we decided to establish hematological reference values in Togo by studying healthy Togolese adults from voluntary blood donors recruited in the National Blood Transfusion Center of Lomé.

\section{Subjects and Methods}

2.1. Subjects. Between April 2008 and September 2008, 2571 blood donor volunteers (less than three donations) were received at the National Blood Transfusion Center of Lomé and gave their informed consent for the study. For each of them, a total blood cell count was performed. Moreover, a peripheral blood film was done in order to detect abnormalities of RBC (mainly hypochromia) and all samples were tested for HIV, HBV, and HCV viral infection, and malaria. The classical method of hemoglobin electrophoresis with integration by densitometry was performed for thalassemia screening in all cases. 
The criteria for inclusion in our study were the following: negativity of all serological tests for viral infections and for malaria, normal hemoglobin electrophoresis screening, and absence of hypochromia on peripheral blood smear. According to these criteria, only 1349 (52\%) subjects were finally retained for the study.

2.2. Blood Collection. All samples were collected between 7.00 a.m. and 11.30 a.m. at the National Blood Transfusion Center of Lomé and analyzed at the day of collection.

All blood was collected with a Vacutainer system in $5 \mathrm{~mL}$ EDTA tubes. The serology tests for HIV, HBV, and HCV detections were performed by ELISA (enzyme-linked immunosorbent assay) in the National Blood Transfusion Center of Lomé. Peripheral blood film was performed and stained according to MGG technique. Malaria was tested with the thick drop method.

2.3. Hematological Analysis. A Sysmex SF-3000 automated hematology analyzer was used for whole-blood analysis of hematological parameters.

The instrument automatically counts and gives a printout result of absolute numbers of leukocytes (WBC) $\left(10^{9} / \mathrm{L}\right)$, erythrocytes $(\mathrm{RBC})\left(10^{12} / \mathrm{L}\right)$, hemoglobin $(\mathrm{g} / \mathrm{dL})$, hematocrit (\%), MCV (fl), MCH (pg), MCHC (g/dL), platelets $\left(10^{9} / \mathrm{L}\right)$, neutrophils $\left(10^{9} / \mathrm{L}\right)$, lymphocytes $\left(10^{9} / \mathrm{L}\right)$, eosinophils $\left(10^{9} / \mathrm{L}\right)$, basophils $\left(10^{9} / \mathrm{L}\right)$, and monocytic cells $\left(10^{9} / \mathrm{L}\right)$.

2.4. Statistical Analysis. Data was recorded in the Excel software and analyzed with Epi Info 3.3.2 software. The mean, median, and standard deviation values were calculated for each parameter. Kruskal-Wallis test for two groups was used to compare parameters according to gender. Differences were statistically significant when $p<0.05$.

\section{Results}

Among the 1379 blood donor volunteers, 1047 were males (77.6\%) and 302 were females $(22.4 \%)$; their age ranged from 17 to 58 years.

The means, medians, and 95th percentile references values according to gender for RBC parameters (RBC count, hemoglobin, hematocrit, and hematimetric constants) are presented in Table 1.

Males had higher median $\mathrm{RBC}\left(5.0 \times 10^{12} / \mathrm{L}\right.$ versus $4.5 \times$ $\left.10^{12} / \mathrm{L}\right)$, hemoglobin $(15.1 \mathrm{~g} / \mathrm{dL}$ versus $13.0 \mathrm{~g} / \mathrm{dL})$, hematocrit (42.8\% versus $38.1 \%$ ), MCV ( $85 \mathrm{fl}$ versus $84 \mathrm{fl}$ ), and $\mathrm{MCH}$ (29.7 pg versus $29.3 \mathrm{pg}$ ) than females. The difference of RBC, hemoglobin, hematocrit, MCV, and MCH by gender was statistically different $(p<0.05)$. The medians of MCHC were $35.1 \mathrm{~g} / \mathrm{dL}$ in males and females. No gender difference was observed for MCHC ( $p=0.08)$.

The Table 2 shows the means, medians, and 95th percentile of WBC parameters (WBC, neutrophils, eosinophils, lymphocytes and monocytes counts). The ranges of total WBC count, absolute neutrophil count, and absolute lymphocyte count were, respectively, $1.9-10.1 \times 10^{9} / \mathrm{L}, 0.5-5.4 \times$
$10^{9} / \mathrm{L}$ and $1.1-4.3 \times 10^{9} / \mathrm{L}$. No gender difference was noticed for WBC parameters $(p>0.11)$.

The median platelet count in males was $236 \times 10^{9} / \mathrm{L}$ (range: $120-443 \times 10^{9} / \mathrm{L}$ ) and $247 \times 10^{9} / \mathrm{L}$ (range: $150-436 \times$ $10^{9} / \mathrm{L}$ ) in females. The means by gender were, respectively, $249 \pm 61.2 \times 10^{9} / \mathrm{L}$ for males and $249 \pm 61.2 \times 10^{9} / \mathrm{L}$ for females. Males had lower platelet count than females and the difference was statistically significant $(p=0.004)$.

\section{Discussion}

The aim of our study was to establish hematological reference values which may serve as western African standards for interpretation of laboratory results. Many factors influence the hematological values such as sex, age, ethnic origin, geographic location, season, and genetic disease $[1,2,13]$. Moreover, one of the main problems in African countries is to determined "normal healthy individuals" due to the high prevalence of hemoglobin abnormalities, iron deficiency, and viral and parasitic infections. Therefore, to date, all hematological reference values published for African population do not specify hemoglobin characteristics and iron status of the tested subjects.

The RBC parameters are influenced by several factors especially the abnormalities of hemoglobin synthesis. Those abnormalities can be constitutional (sickle cell disease, alpha- and beta-thalassemia) or acquired (iron deficiency). Thalassemia and iron deficiency display hypochromia. An ideal approach would be to realize high performance liquid chromatography (HPLC) and ferritin measurement to eliminate thalassemia and iron deficiency before selecting subjects for an RBC study. Until now, no publications for hematological reference values have tested all those parameters. In our study, we try to eliminate most of these abnormalities by performing standard hemoglobin electrophoresis and detecting hypochromia on the peripheral blood smear.

Our results as well as those of other African countries are displayed in Table 3. Medians of hemoglobin and hematocrit were higher in males than females, and differences were statistically significant. Our results are similar to those of the studies performed in African countries with an altitude below 2000 meters [5, 7, 9]. At a higher altitude (Ethiopia), results were different with higher hemoglobin and hematocrit levels $[10,12,14]$. In Kenyan's population [8], hemoglobin median was under $10 \mathrm{~g} / \mathrm{dL}$; this result was lower than in most of the other African population $[4,5$, $7,9,15]$. However, the authors did not specify the method used to establish reference sample collection. MCV median and ranges were, respectively, $87 \mathrm{fl}$ and $68.8-97.7 \mathrm{fl}$. It can be hypothesized that the lower median hemoglobin and the low minimal range $\mathrm{MCV}$, which contrast with the normal or higher RBC, may be linked to the presence of alphathalassemia. This study illustrates the difficulty to get healthy individuals for reference values for RBC series.

WBC differential values were obtained by an automated analyzer as reported in several other recent studies. However some authors still used a manual WBC differential count $[7,10]$. The median WBC count was $4.1 \times 10^{9} / \mathrm{L}$ with a 
TABLE 1: Means, medians, and 95th percentile references values by gender for RBC count, hemoglobin, hematocrit, and hematimetric constants.

\begin{tabular}{|c|c|c|c|c|c|c|}
\hline Subject group $(n)$ and parameters & $\operatorname{RBC}\left(10^{12} / \mathrm{L}\right)$ & Hemoglobin $(\mathrm{g} / \mathrm{dL})$ & Hematocrit $(\%)$ & $\mathrm{MCV}(\mathrm{fl})$ & $\mathrm{MCH}(\mathrm{pg})$ & $\mathrm{MCHC}(\mathrm{g} / \mathrm{dL})$ \\
\hline \multicolumn{7}{|c|}{$\operatorname{ALL}(n=1349)$} \\
\hline Means \pm SD & $4.8 \pm 0.5$ & $14.5 \pm 1.7$ & $41 \pm 4.7$ & $85 \pm 4.1$ & $30 \pm 1.8$ & $35 \pm 1.4$ \\
\hline Median & 4.9 & 14.6 & 41.8 & 84.5 & 29.6 & 35.1 \\
\hline $95 \%$ range & $3.1-6.4$ & $10-18.4$ & $28-54$ & $80-99$ & $25-37$ & $29-41$ \\
\hline \multicolumn{7}{|l|}{ Male $(n=1047)$} \\
\hline Means $\pm \mathrm{SD}$ & $4.9 \pm 0.5$ & $14.8 \pm 1.5$ & $42 \pm 4.2$ & $86 \pm 4.2$ & $30 \pm 1.8$ & $35 \pm 1.4$ \\
\hline Median & 5.0 & 15.1 & 42.8 & 85 & 29.7 & 35.1 \\
\hline $95 \%$ range & $3.3-6.4$ & $10-18.4$ & $28-54$ & $80-99$ & $26-36$ & $29-39$ \\
\hline \multicolumn{7}{|l|}{ Female $(n=302)$} \\
\hline Means \pm SD & $4.5 \pm 0.5$ & $13.1 \pm 1.5$ & $38 \pm 4.4$ & $84 \pm 3.1$ & $29 \pm 1.6$ & $35 \pm 1.5$ \\
\hline Median & $4.5(0.000)^{*}$ & $13(0.000)^{*}$ & $38.1(0.000)^{*}$ & $84(0.000)^{*}$ & $29.3(0.000)^{*}$ & $35.1(0.08)^{* *}$ \\
\hline $95 \%$ range & $3.1-6.0$ & $10.3-17.1$ & $28-47$ & $80-95$ & $25-37$ & $30-41$ \\
\hline
\end{tabular}

$* p$ values $<0.05$ : statistically significant difference between males and females

$* * p$ values $>0.05$ : no statistically significant difference between males and females.

TABLE 2: Means, medians, and 95th percentile references values by gender for WBC parameters.

\begin{tabular}{|c|c|c|c|c|c|}
\hline Subject group $(n)$ and parameters & WBC $\left(10^{9} / \mathrm{L}\right)$ & Neutrophils $\left(10^{9} / \mathrm{L}\right)$ & Eosinophils $\left(10^{9} / \mathrm{L}\right)$ & Lymphocytes $\left(10^{9} / \mathrm{L}\right)$ & Monocytes $\left(10^{9} / \mathrm{L}\right)$ \\
\hline \multicolumn{6}{|c|}{$\operatorname{ALL}(n=1349)$} \\
\hline Means \pm SD & $4.3 \pm 1.1$ & $1.7 \pm 0.7$ & $0.2 \pm 0.07$ & $2.2 \pm 0.5$ & $0.2 \pm 0.1$ \\
\hline Median & 4.1 & 1.6 & 0.2 & 2.1 & 0.2 \\
\hline $95 \%$ range & $1.9-10.1$ & $0.5-5.4$ & $0-0.5$ & $1.1-4.3$ & $0.05-0.8$ \\
\hline \multicolumn{6}{|l|}{ Male $(n=1047)$} \\
\hline Means \pm SD & $4.3 \pm 1.0$ & $1.7 \pm 0.65$ & $0.2 \pm 0.05$ & $2.2 \pm 0.55$ & $0.2 \pm 0.13$ \\
\hline Median & 4.1 & 1.6 & 0.2 & 2.1 & 0.2 \\
\hline $95 \%$ range & $1.9-10.1$ & $0.5-5.4$ & $0-0.5$ & $1.1-4.3$ & $0.05-0.8$ \\
\hline \multicolumn{6}{|l|}{ Female $(n=302)$} \\
\hline Means \pm SD & $4.4 \pm 1.1$ & $1.7 \pm 0.71$ & $0.2 \pm 0.09$ & $2.2 \pm 0.57$ & $0.2 \pm 0.15$ \\
\hline Median & $4.2(0.22)^{* *}$ & $1.6(0.78)^{* *}$ & $0.2(0.20)^{* *}$ & $2.2(0.11)^{* *}$ & $0.2(0.53)^{* *}$ \\
\hline $95 \%$ range & $2.2-7.8$ & $0.5-4.4$ & $0-0.5$ & $1.2-4.3$ & $0.05-0.8$ \\
\hline
\end{tabular}

$* p$ values $<0.05$ : statistically significant difference between males and females

$* * p$ values $>0.05$ : no statistically significant difference between males and females.

TABle 3: Means, median, and 95th percentile for platelets count $\left(10^{9} / \mathrm{L}\right)$ by gender.

\begin{tabular}{lccc}
\hline & All & Males & Females \\
& $(n=1349)$ & $(n=1047)$ & $(n=302)$ \\
\hline Means \pm SD & $249 \pm 61.2$ & $246 \pm 61$ & $257 \pm 60$ \\
Median & 239 & 236 & $247(0.004)^{*}$ \\
95th-percentile & $120-443$ & $120-443$ & $150-436$ \\
\hline
\end{tabular}

$* p$ value < 0.05: statistically significant difference between males and females.

range of $1.9-10.1 \times 10^{9} / \mathrm{L}$. Our limit values were lower than those found elsewhere, but the median values were similar to the results of other African studies $[4,5,7,8]$ except the median of WBC count found in the South African's study which was higher [12]. No difference by gender was found, except in Kenya where males had lower values than females.
Neutropenia was found in all black African or American studies $[5,7,10,16]$. The total WBC and absolute neutrophil count were significantly lower in the black population than in all of other groups $[17,18]$. Mechanisms by which black population have lower values of neutrophils is still not clear. The hypothesis of an excess of marginated neutrophils pool is often proposed but a recent study did not confirm it [19].

The platelet count is globally lower among black people than in Caucasians. In our study, males had lower platelet count than females with a significant difference. In males, the median platelet count was $236 \times 10^{9} / \mathrm{L}$ and in females $247 \times 10^{9} / \mathrm{L}$. The same results were observed in other African $[4,5,7,8,20]$, European [1], and North American $[1,2]$ studies. Some authors accused malaria disease, but identical results were found in countries where malaria disease is not endemic (Ethiopia, Europe, North America). The reasons for these differences according to gender are still unclear. 
TABLE 4: Hematological reference values in African countries.

\begin{tabular}{|c|c|c|c|c|c|c|c|c|c|c|c|c|}
\hline & \multicolumn{2}{|c|}{$\operatorname{RBC}\left(10^{12} / \mathrm{L}\right)$} & \multicolumn{2}{|c|}{ Hemoglobin $(\mathrm{g} / \mathrm{dL})$} & \multicolumn{2}{|c|}{ Hematocrit (\%) } & \multirow{2}{*}{$\begin{array}{l}\mathrm{MCV} \\
(\mathrm{fl})\end{array}$} & \multirow{2}{*}{$\begin{array}{c}\text { WBC } \\
\left(10^{9} / \mathrm{L}\right)\end{array}$} & \multirow{2}{*}{$\begin{array}{l}\text { Neutro } \\
\left(10^{9} / \mathrm{L}\right) \\
\end{array}$} & \multirow{2}{*}{$\begin{array}{l}\text { Lympho } \\
\left(10^{9} / \mathrm{L}\right)\end{array}$} & \multirow{2}{*}{$\begin{array}{l}\text { Mono } \\
\left(10^{9} / \mathrm{L}\right)\end{array}$} & \multirow{2}{*}{$\begin{array}{l}\text { Platelet } \\
\left(10^{9} / \mathrm{L}\right) \\
\end{array}$} \\
\hline & Males & Females & Males & Females & Males & Females & & & & & & \\
\hline Our study & $\begin{array}{c}3.3-6.4 \\
(5.0)\end{array}$ & $\begin{array}{c}3.1-6.0 \\
(4.5)\end{array}$ & $\begin{array}{c}10-18.4 \\
(15.1)\end{array}$ & $\begin{array}{c}10.3-17.1 \\
(13)\end{array}$ & $\begin{array}{l}28-54 \\
(42.8)\end{array}$ & $\begin{array}{l}28-47 \\
(38.1)\end{array}$ & $\begin{array}{l}80-99 \\
(84.5)\end{array}$ & $\begin{array}{c}1.9-10.1 \\
(4.1)\end{array}$ & $\begin{array}{c}0.5-5.4 \\
(1.6)\end{array}$ & $\begin{array}{c}1.1-4.3 \\
(2.1)\end{array}$ & $\begin{array}{l}0.05-0.8 \\
(0.2)\end{array}$ & $\begin{array}{c}120-443 \\
(239)\end{array}$ \\
\hline Uganda [5] & $\begin{array}{c}3.8-6.0 \\
(4.9)\end{array}$ & $\begin{array}{c}3.7-5.3 \\
(4.5)\end{array}$ & $\begin{array}{c}11.1-16.8 \\
(14.1)\end{array}$ & $\begin{array}{c}10.1-14.3 \\
(12.5)\end{array}$ & $\begin{array}{c}32.2-47.8 \\
(40.7)\end{array}$ & $\begin{array}{c}29.6-41.4 \\
(36.2)\end{array}$ & $67.7-95.2$ & $\begin{array}{c}3.4-8.7 \\
(5.3)\end{array}$ & $\begin{array}{c}0.84-3.37 \\
(1.8)\end{array}$ & $\begin{array}{c}1.4-4.2 \\
(2.4)\end{array}$ & $\begin{array}{c}0.17-0.59 \\
\quad(0.32)\end{array}$ & $\begin{array}{c}100-297 \\
(198)\end{array}$ \\
\hline $\begin{array}{l}\text { Central } \\
\text { African [7] }\end{array}$ & $\begin{array}{c}4.5-6.1 \\
(5.14)\end{array}$ & $\begin{array}{c}3.42-5.44 \\
\quad(4.5)\end{array}$ & $\begin{array}{c}12.3-17.3 \\
(14.9)\end{array}$ & $\begin{array}{c}9.1-14.9 \\
(12.5)\end{array}$ & $\begin{array}{c}39-52 \\
(45)\end{array}$ & $\begin{array}{c}28-44 \\
(38)\end{array}$ & NA & $\begin{array}{c}2.9-8.3 \\
(5.05)\end{array}$ & NA & $\begin{array}{c}1.4-4.2 \\
(2.5)\end{array}$ & NA & $\begin{array}{c}117-382 \\
(228)\end{array}$ \\
\hline $\begin{array}{l}\text { Ethiopia } \\
{[10]}\end{array}$ & $\begin{array}{c}4.3-5.9 \\
(5.1)\end{array}$ & $\begin{array}{c}3.7-5.2 \\
(4.5)\end{array}$ & $\begin{array}{c}13.9-18.3 \\
(16.1)\end{array}$ & $\begin{array}{c}12.2-16.6 \\
(14.3)\end{array}$ & $\begin{array}{c}41.6-55.1 \\
(48.3)\end{array}$ & $\begin{array}{c}35.3-48.8 \\
(42)\end{array}$ & NA & $\begin{array}{c}3.0-10.2 \\
\quad(6.1)\end{array}$ & $\begin{array}{c}1.05-7.18 \\
(2.77)\end{array}$ & $\begin{array}{c}0.96-3.47 \\
\quad(1.8)\end{array}$ & $\begin{array}{c}0.17-0.69 \\
(0.32)\end{array}$ & $\begin{array}{c}98-337 \\
(205)\end{array}$ \\
\hline $\begin{array}{l}\text { South Africa } \\
{[12]}\end{array}$ & $\begin{array}{c}3.2-5.8 \\
(4.6)\end{array}$ & $\begin{array}{c}3.0-5.3 \\
(4.2)\end{array}$ & $\begin{array}{l}10.3-16.7 \\
\quad(14)\end{array}$ & $\begin{array}{c}9.0-15.2 \\
(12.4)\end{array}$ & $\begin{array}{c}31-52.5 \\
(42.3)\end{array}$ & $\begin{array}{c}27.3-47.2 \\
(37.6)\end{array}$ & NA & $\begin{array}{c}3.7-12.6 \\
(7.2)\end{array}$ & NA & NA & NA & NA \\
\hline Gambia [4] & NA & NA & $11.1-16.6$ & $9.8-15.0$ & & & $84.3-87.5$ & $3.3-8.4$ & NA & NA & NA & $124-397$ \\
\hline Kenya [8] & $\begin{array}{c}4.4-6.3 \\
(5.3)\end{array}$ & $\begin{array}{c}3.7-5.6 \\
(4.8)\end{array}$ & $\begin{array}{c}8.3-11.3 \\
(9.9)\end{array}$ & $\begin{array}{c}5.9-10 \\
(8.44)\end{array}$ & $\begin{array}{c}40-50 \\
(47)\end{array}$ & $\begin{array}{c}30-50 \\
(40)\end{array}$ & $\begin{array}{c}68.8-97.2 \\
(87)\end{array}$ & $\begin{array}{c}2.8-8.2 \\
(4.4)\end{array}$ & $\begin{array}{c}0.9-4.7 \\
(1.85)\end{array}$ & $\begin{array}{c}1.14-3.45 \\
(1.95)\end{array}$ & $\begin{array}{c}0.13-0.6 \\
(0.29)\end{array}$ & $\begin{array}{c}120-411 \\
(226)\end{array}$ \\
\hline Tanzania [9] & $4.4-6.3$ & $3.8-5.6$ & $13.7-17.7$ & $11.1-15.7$ & $40.2-53.7$ & $36.2-46.8$ & NA & $3.0-7.9$ & $1.1-4.7$ & NA & NA & $150-395$ \\
\hline
\end{tabular}

*(Reference ranges) and median values, NA: not available, Neutro: neutrophils, Lympho: lymphocytes, and Mono: monocytes.

\section{Conclusion}

In spite of the factors influencing hematological values, this study permitted to establish the hematological reference values in Togo. The median values are similar to the ones found in other studies performed in Africa and even in northern countries. The ranges of different parameters are often different especially for RBC considering the influence of alpha-thalassemia and iron deficiency. The reason for lower absolute neutrophil count is still unclear. In the absence of previously hematological reference values in Togo, we offered to use these results for clinical management of Togolese patients and interpretations of laboratory data for research purpose.

\section{Acknowledgments}

The authors acknowledge all the staff of the National Blood Transfusion Center of Lomé where subjects were received and serological tests were performed, and the hematology laboratory of the Campus Teaching Hospital and the technicians of Perfect-Labo where the total blood cell count with differential was performed. They also acknowledge all the personnel of Hematology Laboratory of Henri-Mondor Hospital for their support.

\section{References}

[1] B. Bain, "Normal ranges," in Blood cells-A Practical Guide, Blackwell Scientific Publications, Oxford, UK, 3th edition, 2002.

[2] S. M. Lewis, "Reference ranges and normal values," in Dacie and Lewis_Practical Haematology, S. M. Lewis, B. J. Bain, and I. Bates, Eds., pp. 11-24, Churchill Levingstone, New York, NY, USA, 3th edition, 2006.
[3] R. Giorno, J. H. Clifford, S. Beverly, and R. G. Rossing, "Hematology reference values. Analysis by different statistical technics and variations with age and sex," American Journal of Clinical Pathology, vol. 74, no. 6, pp. 765-770, 1980.

[4] I. M.O. Adetifa, P. C. Hill, D. J. Jeffries et al., "Haematological values from a Gambian cohort-possible reference range for a West African population," International Journal of Laboratory Hematology, vol. 31, no. 6, pp. 615-622, 2009.

[5] E. S. Lugada, J. Mermin, F. Kaharuza et al., "Population-Based Hematologic and Immunologic Reference Values for a Healthy Ugandan Population," Clinical and Diagnostic Laboratory Immunology, vol. 11, no. 1, pp. 29-34, 2004.

[6] O. Rakoto Alson, M. Ratsitorahina, P. Pfister, R. Laganier, and J. A. Dromigny, "Estimation of normal hemogram values in Madagascar," Archives de l"Institut Pasteur de Madagascar, vol. 66, no. 1-2, pp. 68-71, 2000.

[7] D. Menard, M. J. Mandeng, M. B. Tothy, E. K. Kelembho, G. Gresenguet, and A. Talarmin, "Immunohematological reference ranges for adults from the Central African Republic," Clinical and Diagnostic Laboratory Immunology, vol. 10, no. 3, pp. 443-445, 2003.

[8] R. S. Kibaya, C. T. Bautista, F. K. Sawe et al., "Reference ranges for the clinical laboratory derived from a rural population in Kericho, Kenya," PLoS ONE, vol. 3, no. 10, Article ID e3327, 2008.

[9] E. Saathoff, P. Schneider, V. Kleinfeldt et al., "Laboratory reference values for healthy adults from southern Tanzania," Tropical Medicine and International Health, vol. 13, no. 5, pp. 612-625, 2008.

[10] A. Tsegaye, T. Messele, T. Tilahun et al., "Immunohematological reference ranges for adult ethiopians," Clinical and Diagnostic Laboratory Immunology, vol. 6, no. 3, pp. 410-414, 1999.

[11] A. Y. Segbena, C. Prehu, H. Wajcman et al., "Hemoglobins in Togolese newborns: $\mathrm{Hb} \mathrm{S}, \mathrm{Hb} \mathrm{C}, \mathrm{Hb}$ Bart's, and $\alpha$-globin 
gene status," American Journal of Hematology, vol. 59, no. 3, pp. 208-213, 1998.

[12] G. J. Ruiz-Arguelles, L. Sanchez-Medal, and A. Loria, "Red cell indices in normal adults residing at altitudes from sea level to 2670 meters," American Journal of Hematology, vol. 8, no. 3, pp. 265-271, 1980.

[13] C. K.-W. Cheng, J. Chan, G. S. Cembrowski, and O. W. van Assendelft, "Complete blood count reference interval diagrams derived from NHANES III: stratification by age, sex, and race," Laboratory Hematology, vol. 10, no. 1, pp. 42-53, 2004.

[14] F. León-Velarde, A. Gamboa, J. A. Chuquiza, W. A. Esteba, M. Rivera-Chira, and C. C. Monge, "Hematological parameters in high altitude residents living at 4355, 4660, and 5500 meters above sea level," High Altitude Medicine and Biology, vol. 1, no. 2, pp. 97-104, 2000.

[15] C. J. Badenhorst, J. Fourie, K. Steyn et al., "The haematological profile of urban black Africans aged 15-64 years in the Cape Peninsula," East African Medical Journal, vol. 72, no. 1, pp. 1924, 1995.

[16] F. Sahr, P. K. Hazra, and T. A. Grillo, "White blood cell count in healthy Sierra Leoneans," West African Journal of Medicine, vol. 14, no. 2, pp. 105-107, 1995.

[17] B. Bain, M. Seed, and I. Godsland, "Normal values for peripheral blood white cell counts in women of four different ethnic origins," Journal of Clinical Pathology, vol. 37, no. 2, pp. 188-193, 1984.

[18] M. M. Hsieh, J. E. Everhart, D. D. Byrd-Holt, J. F. Tisdale, and G. P. Rodgers, "Prevalence of neutropenia in the U.S. population: age, sex, smoking status, and ethnic differences," Annals of Internal Medicine, vol. 146, no. 7, pp. 486-492, 2007.

[19] D. Phillips, K. Rezvani, and B. J. Bain, "Exercise induced mobilisation of the marginated granulocyte pool in the investigation of ethnic neutropenia," Journal of Clinical Pathology, vol. 53, no. 6, pp. 448-483, 2000.

[20] S. M. Gevao, E. Pabs-Garnon, and A. C. Williams, "Platelet counts in healthy adult Sierra Leoneans," West African Journal of Medicine, vol. 15, no. 3, pp. 163-164, 1996. 


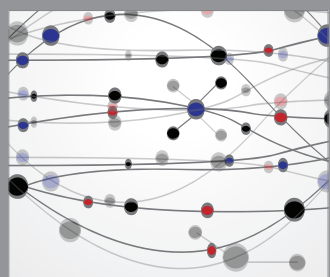

The Scientific World Journal
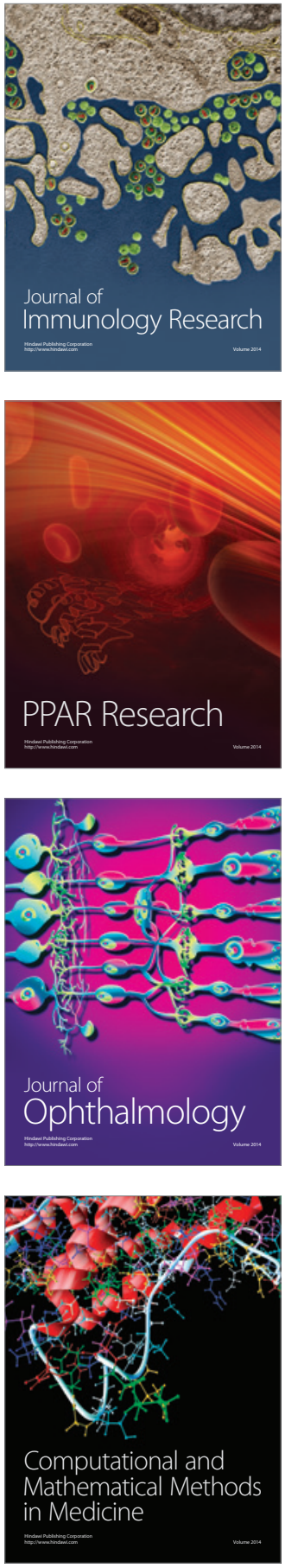

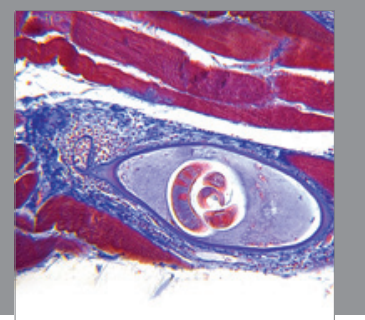

Gastroenterology

Research and Practice
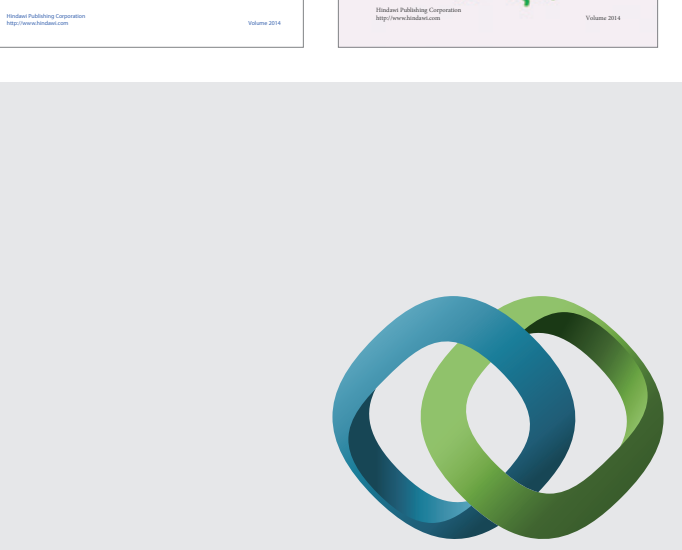

\section{Hindawi}

Submit your manuscripts at

http://www.hindawi.com
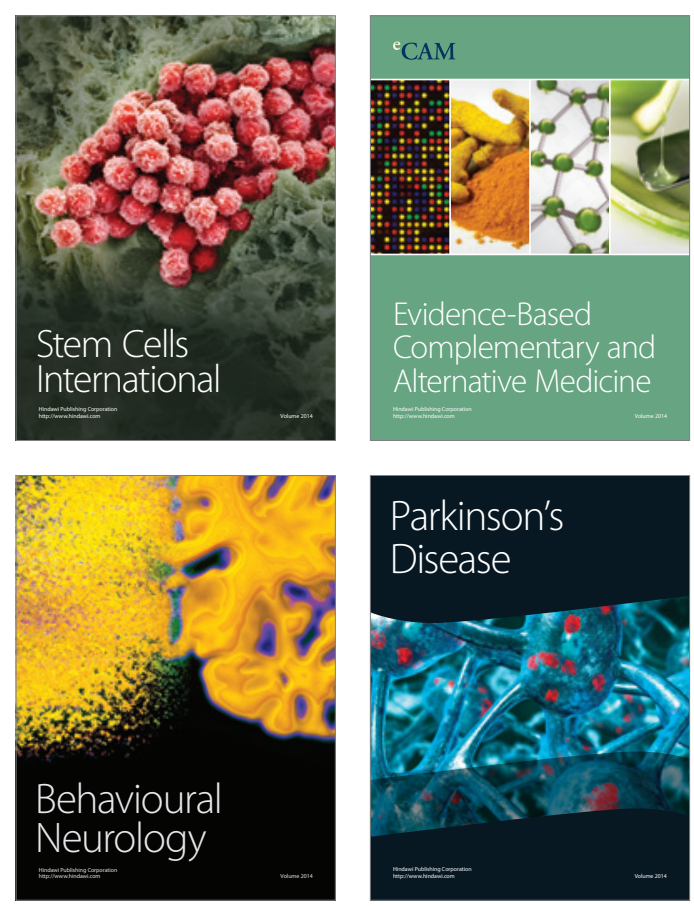

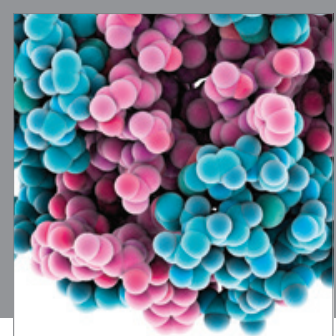

Journal of
Diabetes Research

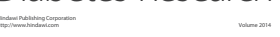

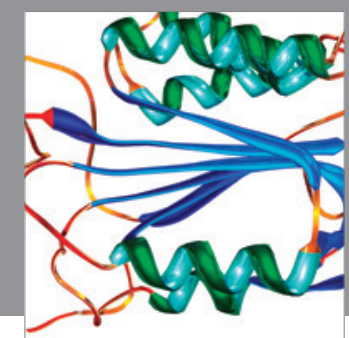

Disease Markers
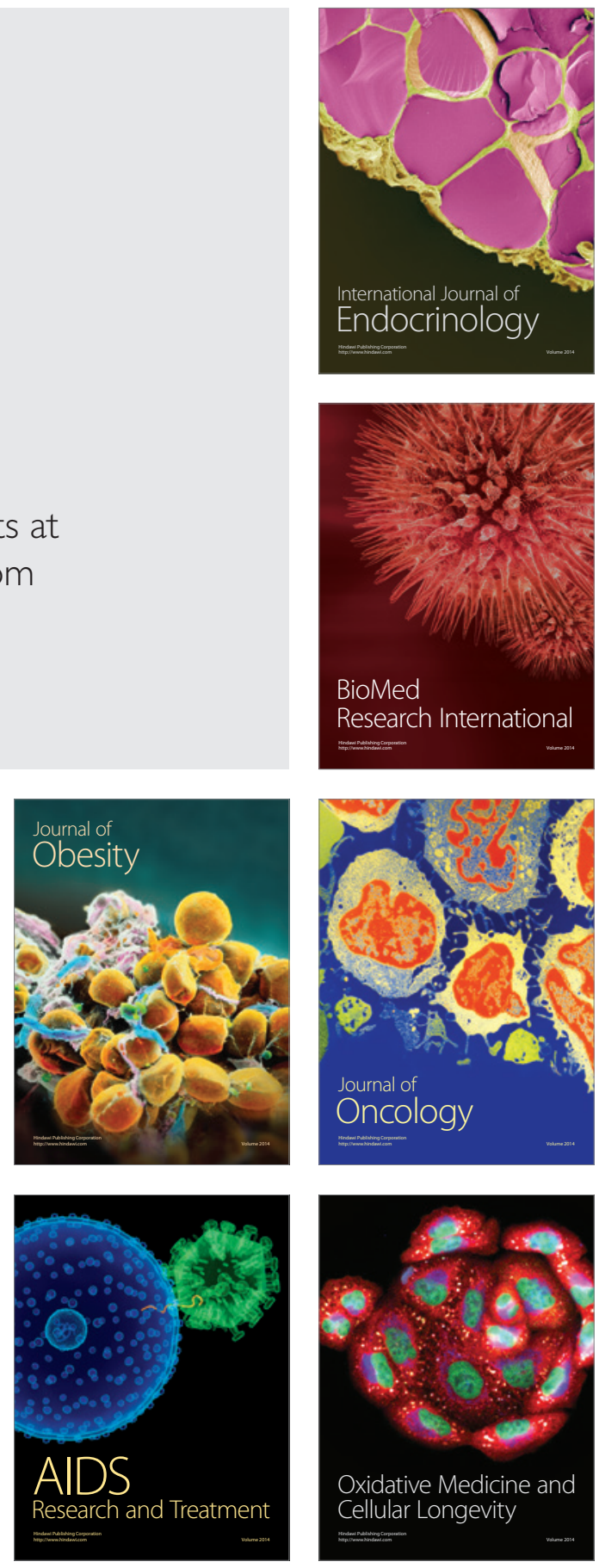